\title{
Efektivitas Air Perasan Jeruk Nipis (Citrus aurantifolia) dalam Menghambat Pertumbuhan Escherichia coli
}

\author{
Ratih Dewi Dwiyanti, Hana Nailah, Ahmad Muhlisin, Leka Lutpiatina \\ Jurusan Analis Kesehatan Poltekkes Kemenkes Banjarmasin \\ Jl Mistar Cokrokusumo 4a Banjarbaru \\ e-mail: leka.zns@gmail.com
}

\begin{abstract}
Lime (Citrus aurantifolia) can be used for cough medicine, sputum laxative, influenza, and acne medication. Lime contains useful chemical compounds, one of which is essential oils and flavonoids which function as antibacterials. The purpose of this study was to determine the effectiveness of lime juice (Citrus aurantifolia) at a concentration of $10 \%, 20 \%, 30 \%, 40 \%, 50 \%, 60 \%, 70 \%, 80 \%, 90 \%$ and $100 \%$ on the growth of Escherichia coli in vitro. This research is experimental with post test only control group design. The research sample was lime juice. Antibacterial power testing using well diffusion method. Antibacterial power parameters were determined by measuring the inhibitory zone $(\mathrm{mm})$ formed around the growth of test bacteria on Muller Hinton Agar media. The results of the study showed that lime juice inhibition zones against the growth of Eschericia coli at concentrations of $40 \%, 50 \%, 60 \%, 70 \%, 80 \%, 90 \%$ and $100 \%$ were $7.25 \mathrm{~mm}, 13.25 \mathrm{~mm}, 14.25 \mathrm{~mm}, 16 \mathrm{~mm}, 17 \mathrm{~mm}, 18.25 \mathrm{~mm}$, and $20.75 \mathrm{~mm}$. Based on linear regression test obtained significant value of $0.000<\alpha 0.05$ so it can be concluded that there is an effect of lime juice on Eschericia coli growth in vitro.
\end{abstract}

Keyword : Lime, Eschericia coli, Antibacterial

Abstrak: Jeruk nipis (Citrus aurantifolia) dapat digunakan untuk obat batuk, peluruh dahak, influenza, dan obat jerawat. Jeruk nipis mengandung senyawa kimia yang bermanfaat salah satunya minyak atsiri dan flavonoid yang berfungsi sebagai antibakteri. Tujuan penelitian ini untuk mengetahui efektivitas air perasan jeruk nipis (Citrus aurantifolia) pada konsentrasi 10\%, 20\%, 30\%, 40\%, 50\%, 60\%, 70\%, 80\%, 90\% dan $100 \%$ terhadap pertumbuhan Eschericia coli secara in vitro. Penelitian ini bersifat eksperimen dengan rancangan post test only control group design. Sampel penelitian adalah air perasan jeruk nipis. Pengujian daya antibakteri menggunakan metode difusi sumuran. Parameter daya antibakteri ditentukan dengan mengukur zona hambat $(\mathrm{mm})$ yang terbentuk di sekitar pertumbuhan bakteri uji pada media Muller Hinton Agar. Hasil Penelitian menunjukkan zona hambat air perasan jeruk nipis terhadap pertumbuhan Eschericia coli pada konsentrasi 40\%, 50\%, 60\%, 70\%, 80\%, 90\% dan 100\% masingmasing berdiameter $7,25 \mathrm{~mm}, 13,25 \mathrm{~mm}, 14,25 \mathrm{~mm}, 16 \mathrm{~mm}, 17 \mathrm{~mm}, 18,25 \mathrm{~mm}$, dan $20,75 \mathrm{~mm}$. Berdasarkan uji regresi linear didapat nilai signifikan $0,000<\alpha 0,05$ sehingga dapat disimpulkan bahwa ada pengaruh air perasan jeruk nipis terhadap pertumbuhan Eschericia coli secara in vitro.

Kata Kunci: Madu Lebah Kelulut (Trigona spp.); Staphylococcus aureus resisten

Corresponding Author:

Politeknik Kesehatan Banjarmasin

Ratih Dewi Dwiyanti,

Jurusan Analis Kesehatan Poltekkes Kemenkes Banjarmasin

JIn H. Mistar Cokrokusumo No.1A Banjarbaru

Email : leka.zns@gmail.com 


\section{PENDAHULUAN}

Jeruk nipis merupakan salah satu buah yang banyak digemari oleh masyarakat di Indonesia. Jeruk nipis yang bernama latin Citrus aurantifolia ialah salah satu jenis tanaman yang banyak tumbuh dan dikembangkan di Indonesia. Selain itu jeruk nipis juga dapat digunakan untuk obat batuk, peluruh dahak, influenza, dan obat jerawat. Buah ini banyak dikonsumsi masyarakat dan mempunyai harga relatif murah, mudah diperoleh, alamiah, serta tidak menimbulkan efek samping bagi pemakainya (1).

Jeruk nipis juga sering digunakan masyarakat Indonesia sebagai campuran pada makanan untuk memberi rasa asam sehingga menambah rasa segar pada makanan itu sendiri, salah satunya pada makanan khas Kalimantan Selatan yaitu Soto Banjar (2)

Jeruk nipis mengandung unsur - unsur senyawa kimia yang bemanfaat, seperti asam sitrat, asam amino, minyak atsiri, damar, glikosida, asam sitrun, lemak, kalsium, fosfor, besi, belerang vitamin B1 dan C. Kandungan Gizi dalam 100gram buah jeruk nipis mengandung vitamin C sebesar 27 miligram, kalsium 40 miligram, fosfor 22 miligram, hidrat arang 12,4 gram, vitamin B1 0,04 miligram, zatbesi0,6 miligram, lemak 0,1 gram, kalori 37 gram, protein 0,8 gram dan mengandung air 86 gram (3).

Minyak atsiri yang terkandung dalam jeruk nipis mempunyai fungsi sebagai antibakteri, salah satu kandungan lainnya yaitu flavonoid, berperan sangat penting dalam menghambat pertumbuhan bakteri (4).

Berdasarkan penelitian yang telah dilakukan Razak (2013) air perasan jeruk nipis terbukti efektif dalam menurunkan pertumbuhan Staphylococcus aureus. Air Perasan buah jeruk nipis memiliki daya hambat terhadap pertumbuhan dari bakteri Staphylococcus aureus pada konsentrasi 25\%, 50\%,75\%, dan 100\%, semakin tinggi konsentrasi air perasan buah jeruk nipis maka daya hambat air perasan buah jeruk nipis terhadap pertumbuhan bakteri Staphylococcus aureus semakin baik. Terdapat pengaruh lama waktu kontak air perasan buah jeruk nipis terhadap pertumbuhan bakteri Staphylococcus aureus yaitu semakin lama kontak bakteri Staphylococcus aureus dengan air perasan buah jeruk nipis maka daya hambat perasan buah jeruk nipis terhadap pertumbuhan bakteri Staphylococcus aureus semakin baik, tepatnya air perasan buah jeruk nipis sudah memiliki daya hambat terhadap pertumbuhan bakteri Staphylococcus aureus dalam kontak 5 menit (5).

Efek air perasan jeruk nipis sebagai antibakteri dapat menghambat pertumbuhan bakteri Eschericia coli, Streptococcus haemolyticus, dan Staphylococcus aureus. Eschericia coli adalah salah satu jenis spesies utama bakteri gram negatif, berbentuk batang pendek (kokobasil). Escherichia coli dapat bertahan hingga suhu $60^{\circ} \mathrm{C}$ selama 15 menit atau pada $55^{\circ} \mathrm{C}$ selama 60 menit. Hidup pada tinja dan menyebabkan masalah kesehatan pada manusia, seperti diare, muntaber serta masalah pencernaan lainnya (6). Escherichia coli adalah kuman oportunis yang banyak ditemukan di dalam usus besar manusia sebagai flora normal. Sifatnya unik karena dapat menyebabkan infeksi primer pada usus misalnya diare pada anak, seperti juga kemampuannya menimbulkan infeksi pada jaringan tubuh lain diluar usus (7). Penelitian ini bertujuan untuk mengetahui efektivitas air perasan jeruk nipis (Citrus aurantifolia) dalam menurunkan jumlah bakteri Eschericia coli secara in vitro.

\section{BAHAN DAN METODE}

Penelitian ini merupakan penelitian eksperimen sebenarnya (true eksperimen) 
dengan rancangan penelitian Post Test Only Control Group Design, yaitu dengan melakukan pemeriksaan daya hambat dari air perasan jeruk nipis (Citrus aurantifolia) dengan konsentrasi 10\%, 20\%, 30\%, 40\%, 50\%, 60\%,70\%, 80\%, 90\% dan $100 \%$ kemudian dibandingkan dengan kelompok kontrol.

Sampel yang digunakan dalam penelitian ini adalah jeruk nipis (Citrus aurantifolia) yang akan dibuat 10 konsentrasi, yaitu 10\%, 20\%, 30\%, 40\%,50\%, 60\%, $70 \%, 80 \%$, 90\% dan 100\%. Sampel jeruk nipis (Citrus aurantifolia) yang digunakan adalah dengan kriteria jeruk nipis lokal, segar, dan berwarna hijau bersih. Bahan yang digunakan dalam penelitian adalah air perasan jeruk nipis, biakan Escherichia coli, media Mac Conkey (Merck), media Muller Hinton (Merck), $\mathrm{NaCl}$ 0,9\% steril, aquadest, standar Mc Farland 0,5.

Cara pengumpulan data dalam penelitian ini adalah data primer yang diperoleh dari hasil penelitian atau percobaan yang dilakukan di laboratorium berupa pemeriksaan daya hambat perasan air jeruk nipis (Citrus aurantifolia) berbagai konsentrasi terhadap Escherichia coli. Hasil akhir akan ditentukan dengan mengukur zona hambat yang terbentuk menggunakan skala data rasio dari zona hambat air perasan jeruk nipis (Citrus aurantifolia) terhadap Escherichia coli yang dinyatakan dalam milimeter (mm).

Uji determinasi terhadap jeruk nipis (Citrus aurantifolia) di Laboratorium Dasar FMIPA Universitas Lambung Mangkurat Banjarbaru. Uji antibakteri dengan metode difusi secara sumuran dengan cara permukaan media Muller Hinton, diteteskan bakteri Escherichia coli sebanyak $10 \mu \mathrm{l}$, kemudian diratakan dengan segitiga bengkok dan didiamkan selama 15 menit. Dibuat sumuran berdiameter $6 \mathrm{~mm}$ dengan menggunakan cork borer pada media Muller Hinton. Untuk kontrol negatif, dimasukkan $50 \mu \mathrm{l}$ aquadest steril ke dalam sumuran pada media Muller Hinton. Untuk kontrol positif, diletakkan disc Seftriakson $30 \mathrm{mcg}$ ke dalam sumuran pada media Muller Hinton. Untuk sampel, dimasukkan $50 \mu \mathrm{l}$ air perasan jeruk nipis (Citrus aurantifolia) yang telah dibuat seri pengenceran yang berbeda yaitu 10\%, 20\%, 30\%, 40\%,50\%, 60\%, 70\%, 80\%, 90\% dan $100 \%$ ke dalam sumuran pada media Muller Hinton. Diinkubasi pada suhu $37^{\circ} \mathrm{C}$ selama 24 jam. Dari hasil yang diperoleh dilakukan pembacaan dengan mengukur zona hambat air perasan jeruk nipis terhadap Escherichia coli menggunakan penggaris.

Interpretasi hasil obat Seftriakson terhadap Escherichia coli:

Resisten : $<19 \mathrm{~mm}$.

Intermediet : $20-22 \mathrm{~mm}$.

Sensitif $\quad:>23 \mathrm{~mm}$.

\section{HASIL DAN PEMBAHASAN}

Pengujian antimikroba Air Perasan Jeruk Nipis terhadap Escherichia coli memperlihatkan adanya variasi zona hambat. Data zona hambat Air Perasan Jeruk Nipis, Kontrol Positif, dan Kontrol Negatif disajikan pada tabel 1. 
Tabel 1 Zona hambat Air Perasan Jeruk Nipis terhadap Escherichia coli pada berbagai konsentrasi.

\begin{tabular}{|c|c|c|c|c|c|}
\hline \multirow{2}{*}{$\begin{array}{l}\text { Variasi } \\
\text { Konsentrasi } \\
\text { (\%) }\end{array}$} & \multicolumn{5}{|c|}{$\begin{array}{l}\text { Zona Hambat Terhadap Pertumbuhan Escherichia coli } \\
\text { (dalam mm) }\end{array}$} \\
\hline & $\begin{array}{l}\text { Pengulang } \\
\text { an Ke-1 }\end{array}$ & $\begin{array}{l}\text { Pengulang } \\
\text { an ke-2 }\end{array}$ & $\begin{array}{l}\text { Pengulang } \\
\text { an Ke-3 }\end{array}$ & $\begin{array}{l}\text { Pengulang } \\
\text { an Ke-4 }\end{array}$ & $\begin{array}{l}\text { Rata- } \\
\text { rata }\end{array}$ \\
\hline $10 \%$ & 0 & 0 & 0 & 0 & 0 \\
\hline $20 \%$ & 0 & 0 & 0 & 0 & 0 \\
\hline $30 \%$ & 0 & 0 & 0 & 0 & 0 \\
\hline $40 \%$ & 6 & 6 & 8 & 9 & 7,25 \\
\hline $50 \%$ & 18 & 11 & 11 & 13 & 13,25 \\
\hline $60 \%$ & 13 & 15 & 15 & 14 & 14,25 \\
\hline $70 \%$ & 15 & 16 & 16 & 17 & 16 \\
\hline $80 \%$ & 16 & 17 & 17 & 18 & 17 \\
\hline $90 \%$ & 18 & 18 & 17 & 20 & 18,25 \\
\hline $100 \%$ & 22 & 20 & 20 & 21 & 20,75 \\
\hline $\begin{array}{l}\text { Kontrol negatif } \\
\text { (aquades) }\end{array}$ & 0 & 0 & 0 & 0 & 0 \\
\hline $\begin{array}{l}\text { Kontrol Positif } \\
\text { (Seftriakson) }\end{array}$ & 44 & 46 & 43 & 47 & 45 \\
\hline
\end{tabular}

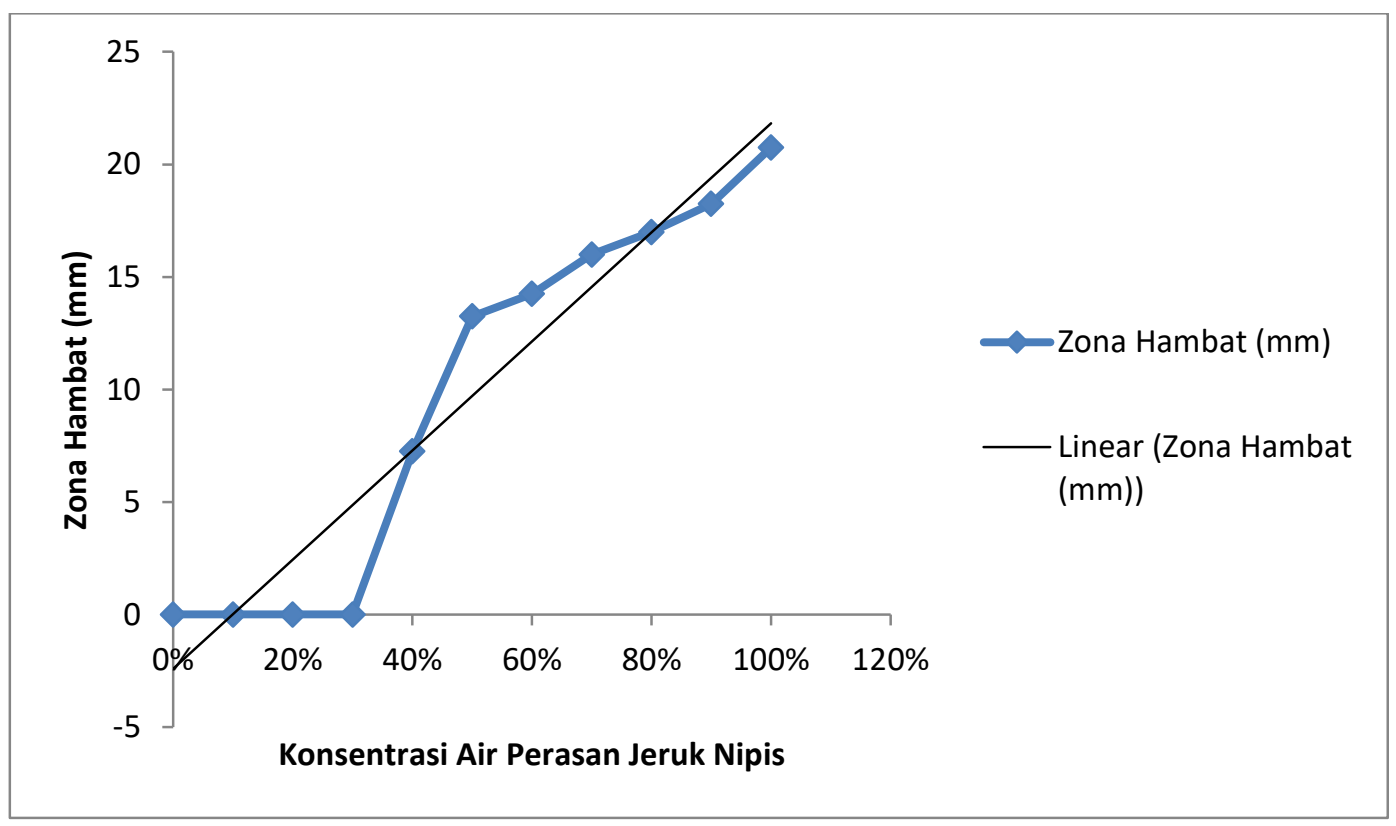

Gambar 1 Grafik zona hambat air perasan jeruk nipis pada berbagai konsentrasi terhadap pertumbuhan Escherichia coli.

Pada gambar 1 menunjukkan bahwa terjadi peningkatan zona hambat terhadap Escherichia coli pada Air Perasan Jeruk Nipis dari konsentrasi 40\% (7,25mm), 50\% $(13,25 \mathrm{~mm}), 60 \%(14,25 \mathrm{~mm}), 70 \%(16 \mathrm{~mm}), 80 \%(17 \mathrm{~mm}), 90 \%(18,25 \mathrm{~mm})$ dan $100 \%$ 
$(20,75 \mathrm{~mm})$. Berdasarkan hasil tersebut maka dilakukan uji statistik, uji normalitas terlebih dahulu, untuk mengetahui apakah data yang digunakan terdistribusi normal atau tidak. Karena syarat uji regresi data harus terdistribusi normal.

Dari hasil uji normalitas data dengan menggunakan Uji Shapiro-Wilk, diketahui nilai asymp, sig semua data yang pada Tabel 2 semuanya melebihi dari 0,05 . Apabila nilai asymp, sig > 0,05 maka dapat dinyatakan bahwa data pada tabel 1 terdistribusi normal. Kemudian dilanjutkan dengan uji Anova. Berdasarkan hasil Uji Anova diperoleh nilai signifikan 0,000 apabila nilai signifikan $<\alpha=0,05$, maka dapat dilanjutkan ke Uji Regresi.

Berdasarkan hasil uji analisa statistik menggunakan uji regresi didapatkan nilai signifikasi $=0,000$. Sesuai ketentuan apabila nilai signifikasi $<\alpha=0,05$ maka dapat dinyatakan bahwa berbagai konsentrasi yang berbeda dari air perasan jeruk nipis berpengaruh terhadap pertumbuhan Escherichia coli secara in vitro. Dengan Persamaan $y=2,425 x-4.845$ ( $x=$ konsentrasi, $y=$ zona hambat). Untuk melihat seberapa besar pengaruh konsentrasi air perasan jeruk nipis terhadap pertumbuhan Escherichia coli, terhadap peningkatan zona hambat dilakukan analisis koefisien determinasi atau disimbolkan dengan $\mathrm{R}^{2}$ yang merupakan hasil dari pengujian terhadap pengingkatan zona hambat. Nilai R square sebesar 0,902 atau sebesar $90,2 \%$ nilai ini menyimpulkan bahwa konsentrasi air perasan jeruk nipis terhadap peningkatan diameter zona hambat Escherichia coli sebesar 90,2\%.

Penelitian ini dilakukan untuk mengetahui bahwa air perasan jeruk nipis (Citrus aurantifolia) dapat menghambat pertumbuhan bakteri Escherichia coli. Pada penelitian ini menggunakan aquades sebagai pengencer pada pembuatan berbagai konsentrasi air perasan jeruk nipis.

Aktivitas antibakteri dari air perasan jeruk nipis dapat diketahui dengan mengukur diameter zona hambat yang terbentuk pada media Muller Hinton Agar. Berdasarkan data yang diperoleh diketahui bahwa air perasan jeruk nipis mempunyai kemampuan dalam menurunkan jumlah bakteri Escherichia coli dengan cara menghambat pertumbuhan bakteri tersebut. Tidak semua konsentrasi air perasan jeruk nipis dapat menghambat pertumbuhan bakteri Escherichia coli hal itu dapat dilihat dengan tidak terbentuknya zona hambat pada konsentrasi $10 \%, 20 \%$ dan $30 \%$. Hal ini dapat terjadi karena zat aktif yang berperan sebagai antibakteri pada air perasan jeruk nipis dengan konsentrasi tersebut jumlahnya belum mencukupi untuk bisa menghambat bakteri Escherichia coli. Zona hambat yang terbentuk dimulai pada konsentrasi $40 \%$. Dari hasil penelitian didapatkan nilai rata-rata diameter zona hambat yang terbentuk pada konsentrasi $40 \%$ adalah 7,25 , konsentrasi $50 \%$ adalah $13,25 \mathrm{~mm}$, konsentrasi $60 \%$ adalah $14,25 \mathrm{~mm}$, konsentrasi $70 \%$ adalah $16 \mathrm{~mm}$, konsentrasi $80 \%$ adalah $17 \mathrm{~mm}$, konsentrasi $90 \%$ adalah $18,25 \mathrm{~mm}$, konsentrasi $100 \%$ adalah $20,75 \mathrm{~mm}$. Nilai rata-rata diameter zona hambat tersebut didapatkan dari 4 pengulangan pada setiap perlakuan konsentrasi air perasan jeruk nipis. Konsentrasi $100 \%$ menghasilkan diameter terbesar yaitu $20,75 \mathrm{~mm}$. Namun hasil tersebut masih tidak seefektif jika dibandingkan dengan kontrol positifnya yaitu Seftriakson dengan rata-rata diameter zona hambat sebesar $45 \mathrm{~mm}$.

Berdasarkan hasil penelitian diketahui bahwa adanya variasi diameter zona hambat yang terbentuk disebabkan oleh perbedaan konsentrasi air perasan jeruk nipis. Semakin tinggi konsentrasi air perasan jeruk nipis maka semakin besar diameter zona hambat yang terbentuk serta semakin besar kemampuan penghambatan yang ditimbulkan. Hal ini menunjukkan bahwa dengan meningkatnya konsentrasi air perasan jeruk nipis maka 
semakin besar pula kandungan bahan aktif yang terdapat dalam air perasan jeruk nipis yang berfungsi sebagai antibakteri, sehingga semakin besar kemampuannya dalam menghambat pertumbuhan bakteri (8).

Kemampuan suatu bahan antibakteri dalam menghambat hidup mikroorganisme tergantung pada konsentrasi bahan antibakteri (8). Artinya jumlah bahan antibakteri dalam suatu lingkungan kuman sangat menentukan kehidupan kuman yang terpapar. Dalam penelitian ini nilai konsentrasi yang digunakan berupa persentase sebagai perbandingan jumlah air perasan jeruk nipis dengan pengencernya.

Pertumbuhan bakteri dapat dihambat oleh kandungan minyak atsiri dan flavonoid yang ada pada jeruk nipis. Minyak atsiri tersebut bekerja dengan cara mendenaturasi protein sel bakteri dan merusak membran sitoplasma sel. Protein yang mengalami proses denaturasi akan kehilangan aktifitas fisiologis dan ketidakstabilan pada dinding sel akan meningkatkan permeabilitas sel, fungsi pengangkutan menjadi aktif, pengendalian susunan protein sel bakteri terganggu sehingga berakibat pada lolosnya makro molekul dan ion dari sel. Sel akan kehilangan bentuknya sehingga lisis dan mengalami kerusakan. Sedangkan flavonoid memiliki sifat bakteriostatik atau bakterisid tergantung dengan konsentrasinya, menghambat pertumbuhan bakteri dengan cara berinteraksi langsung dengan DNA, menyebabkan DNA bakteri rusak sehingga bakteri tersebut mati (9). Hal ini dikarenakan DNA atau RNA memegang peranan penting didalam proses kehidupan normal sel. Artinya gangguan apapun yang terjadi pada pembentukan atau pada fungsi zat - zat tersebut dapat mengakibatkan kerusakan total pada sel (10).

Hasil penelitian uji daya hambat air perasaan jeruk nipis terhadap pertumbuhan bakteri Staphylococcus aureus secara in vitro oleh Razak (2013), memperlihatkan adanya aktivitas hambatan terhadap bakteri Staphylococcus aureus pada konsentrasi $25 \%, 50 \%, 75 \%$ dan $100 \%$ dengan rata-rata zona hambat yang terbentuk sebesar 5,167mm, 6,167mm, 7,7mm dan 10,5mm.

Hasil penelitian uji daya hambat air perasaan jeruk nipis terhadap pertumbuhan bakteri Samonella typhi secara in vitro oleh Brilian (2014) menunjukkan adanya peningkatan zona hambat yang terbantuk pada konsentrasi $12,5 \%, 25 \%, 50 \%$, dan $75 \%$ dengan hasil pengukuran diameter zona hambat rata-rata $8,5 \mathrm{~mm}, 16 \mathrm{~mm}, 19,5 \mathrm{~mm}$, dan 23,5mm (11).

\section{KESIMPULAN}

Ada pengaruh air perasan jeruk nipis (Citrus aurantifolia) dalam menurunkan jumlah Escherichia coli pada konsentrasi 40\%, 50\%, 60\%, 70\%, 80\%, 90\% dan 100\% dengan memperlihatkan adanya zona hambat sebesar 7,25mm, 13,25mm, 14,25mm, $16 \mathrm{~mm}, 17 \mathrm{~mm}, 18,25 \mathrm{~mm}$, dan 20,75mm. air perasan jeruk nipis (Citrus aurantifolia) yang paling efektif dalam menurunkan jumlah Escherichia coli adalah konsentrasi 100\% yaitu 20,75mm. Besar pengaruh air perasan jeruk nipis (Citrus aurantifolia) dalam menurunkan jumlah Escherichia coli yaitu sebesar 90,2 \%.

\section{DAFTAR PUSTAKA}

(1) Adina AB, Handoko FF, Setyarini II. "Jeruk Nipis (Citrus aurantifolia)" CCRC Farmasi UGM. 2015

(2) Agus S., Cooking with Love. Indonesia: Gramedia Pustaka Utama. 2014

(3) Lusi, I. N., "Pemanfaatan Kandungan Air Jeruk Nipis (The Utilization Content Water 
Lime)". Jurnal UNEI h. 1-4. 2013

(4) Sudirman, A.T., "Uji Efektivitas Daun salam terhadap pertumbuhan Staphylococcus aureus secara in vitro" (Skripsi). Fakultas Kedokteran Gigi. Universitas Hasanuddin. Makasar. 2014

(5) Razak A, Djamal A, Revilla G., "Uji Daya Hambat Air Perasan Jeruk Nipis (Citrus aurantifolia) Terhadap Pertumbuhan Bakteri Staphylococcus aureus Secara in vitro". Jurnal Kesehatan Andalas. 2013

(6) Brooks GF., Mikrobilogi Kedokteran. Jakarta : Salemba Medika, 2005

(7) Angi., Escherichia coli. Farmasi USD Yogyakarta, 2009

(8) Ajizah, A., 2004. Sensitivitas Salmonella typhimurium Terhadap Ekstrak Daun Psidium guajava L. 2, pp. 31-38.

(9) Sumono, A. \& Wulan, A.,"The use of bay leaf (Eugenia polyantha Wight) in dentisty", Dental Jurnal, Volume 41, 2008

(10) Rahayu, P. \& Winiati, "Aktivitas Antimikroba Bumbu Masakan Tradisional”. Journal of medicinal plant research, Volume 4, 2000

(11) Brillian B., Salmonella infections - Human - Medicine. Universitas Syiah Kuala, 2014 